Article

\title{
Steady-State Modeling of Fuel Cells Based on Atom Search Optimizer
}

\author{
Ahmed M. Agwa ${ }^{1,2, *}$, Attia A. El-Fergany ${ }^{3}(\mathbb{D})$ and Gamal M. Sarhan ${ }^{1}$ \\ 1 Electrical Engineering Department, Faculty of Engineering, Northern Border University, Arar 73222, \\ Saudi Arabia; gamal_bhit@yahoo.com \\ 2 Electrical Engineering Department, Faculty of Engineering, Al-Azhar University, Cairo 11651, Egypt \\ 3 Electrical Power and Machines Department, Faculty of Engineering, Zagazig University, Zagazig 44519, \\ Egypt; el_fergany@ieee.org \\ * Correspondence: ah1582009@yahoo.com
}

Received: 6 May 2019; Accepted: 15 May 2019; Published: 17 May 2019

check for updates

\begin{abstract}
In simulation studies, the precision of fuel cell models has a vital role in the quality of results. Unfortunately, due to the shortage of manufacturer data given in the datasheets, several unknown parameters should be defined to establish the fuel cell model for further precise analysis. This research addresses a novel application of the atom search optimization (ASO) algorithm to generate these unknown parameters of the fuel cell model and in particular of the polymer exchange membrane (PEM) type. The objective of this study is to establish an accurate model of the PEM fuel cells, which will provide accurate results of modeling and simulation in a steady-state condition. Simulations and further demonstrations were performed under MATLAB/SIMULINK. The viability of the proposed models was appraised by comparing its simulation results with the experimental results of number of commercial PEM fuel cells. In the same context, the obtained numerical results by the proposed ASO-based method were compared to other challenging optimization methods-based results. Finally, parametric tests were made which indicated the robustness of the ASO results as well. It can be stated here that ASO performs well and has a good capability to extract the unknown parameters with lesser errors.
\end{abstract}

Keywords: fuel cells; parameter identifications; simulation and modeling; atom search optimizer

\section{Introduction}

Unlike conventional power sources, renewable energy sources as clean energy have received much attention worldwide due to many key reasons, such as the depletion of fossil fuels, price inflations, and other environmental issues. One of the fastest growing and promising renewable energy storage apparatuses is the fuel cell, which can convert fuel chemical energy into electric energy via chemical reactions [1-4]. Today, many assortments of fuel cells are commercialized, such as the polymer exchange membrane (PEM) type for low-operating temperatures [3], and solid-oxide fuel cells for high-operating temperatures [4,5]. PEM fuel cell stays as an incomparable alternative of importance; specifically, in transportation applications, it plays a role in portable electronic implementations and distributed generators. Moreover, its discriminate properties, such as no dissipated generation, high power density, high efficiency, and low operating pressure and temperature, make PEM fuel cell unequaled [3]. The standard efficiency of PEM fuel cell varies between $30 \%$ and $60 \%$ dependent on loading condition, and the operating temperatures range from $30{ }^{\circ} \mathrm{C}$ to $100{ }^{\circ} \mathrm{C}[3-6]$.

Modeling is highly crucial for better comprehension, analysis, design, simulation, and advancement of high efficiency fuel cells. However, the lack of data, number of obscure parameters, and complication in modeling favor the utilization of optimization algorithms [3]. The majority of 
deterministic optimization algorithms have their respective limits, like sensitivity to initial values, and fail to provide dependable results. To ameliorate the accuracy of the PEM fuel cells model parameter estimation, many global optimization algorithms have been used. The results obtained using these algorithms are better than those obtained using traditional methods [6].

Many researchers have endeavored to model PEM fuel cell characteristics using many heuristic based optimization algorithms [7-18] —in particular, the salp swarm optimizer [7], adaptive ribonucleic acid genetic algorithm (ARNA-GA) [8], genetic algorithm [9-11], particle swarm optimizer [12], Taguchi method and genetic algorithm neural networks [13], bird mating optimization algorithm [14], seeker optimizer [15], eclectic hybrid stochastic plan [16], adaptive differential evolution (ADE) algorithm [17], and innovated global harmony search (IGHS) algorithm [18].

Other recent similar optimizers, such as biogeography accompanied by mutation (BBO-M) [19], the simplified teaching-learning based optimizer (STLBO) [20], transmitted adapting differential evolution (TRADE) algorithm [21], hybrid adapting differential evolution (HADE) algorithm [22], nonlinear globally linearizing controller based on an estimator [23], multiverse optimizer (MVO) [24], grasshopper optimization algorithm (GOA) [25], and grey wolf optimizer (GWO) [26], are applied to define the model unknown parameters. In [27], a novel bio-inspired P systems-based optimization algorithm (BIPOA) was introduced to generate the obscure parameters of PEM fuel cells models.

Recently, atom search optimization (ASO), which was developed in 2019, has been utilized in hydro-geologic coefficient estimation [28] and dispersion parameter estimation [29]. In agreement with the no-free lunch theorem, several optimization techniques should be assessed to solve specific problems with attempts to get near/close to optimal solutions. Therefore, ASO is quoted in this current research because its reported results are promising and prove that ASO is superior to other algorithms in parameter estimation $[28,29]$.

In this paper, ASO was used to generate the obscure parameters of two commercial PEM fuel cells. Further validations and comparisons were made to indicate the performance of the proposed ASO-based methodology. The crucial contributions of this research include execution of a novel algorithm, namely ASO, to generate the obscure parameters of the PEM fuel cell model in comparison to other competing methods recently reported in the literature, as well as proving the possibility of benefiting from ASO to optimize several complicated problems in engineering.

The paper is organized as follows: Section 1 gives a brief introduction and survey in this regard. Section 2 illustrates the mathematical modeling of PEM fuel cells. In Section 3, the adapted objective function and constraints are revealed. The ASO procedures are explained in Section 4. Section 5 discusses the obtained results, along with necessary validations. Conclusions are drawn in Section 6 . Finally, acknowledgements, conflicts of interest, and authors' contributions are presented.

\section{Mathematical Modeling of PEM Fuel Cell}

The model of a PEM fuel cell stack was intensively demonstrated in the literature. For a stack consisting of $\mathrm{n}_{\text {cells }}$ series connected cells, the stack's terminal voltage $\mathrm{V}_{\text {stack }}$ can be evaluated by the following equation $[9,25]$ :

$$
\mathrm{V}_{\text {stack }}=\mathrm{n}_{\text {cells }} \cdot\left(\mathrm{E}-\mathrm{V}_{\text {act }}-\mathrm{V}_{\Omega}-\mathrm{V}_{\text {con }}\right) .
$$

By assuming that the $\mathrm{H}_{2}$ flow rate is controllable with regard to the loading condition, it can be revealed that the utilization factor is constant and has a typical value of $95 \%$ [25]. $\mathrm{E}_{\max }$ is the maximum voltage that can be generated by the PEM fuel cell at a higher heating value of $\mathrm{H}_{2}$, which typically equals $1.48 \mathrm{~V} / \mathrm{cell}$ [25]. It is of value to emphasize that the theoretical voltage with respect to the lower heating value is $1.23 \mathrm{~V} / \mathrm{cell}$ (See (2)). The aforementioned variables indicated in (1) are stated as follows:

$$
\mathrm{E}=1.299-0.85 \cdot 10^{-3}\left(\mathrm{~T}_{\mathrm{fc}}-298.15\right)+4.3085 \cdot 10^{-5} \mathrm{~T}_{\mathrm{fc}} \ln \left(\mathrm{P}_{\mathrm{H}_{2}} \sqrt{\mathrm{P}_{\mathrm{O}_{2}}}\right),
$$




$$
\begin{aligned}
& \mathrm{P}_{\mathrm{H}_{2}}=\frac{R \mathrm{H}_{\mathrm{a}} \cdot \mathrm{P}_{\mathrm{H}_{2} \mathrm{O}}}{2}\left[1 /\left(\frac{\mathrm{RH}_{\mathrm{a}} \cdot \mathrm{P}_{\mathrm{H}_{2} \mathrm{O}}}{\mathrm{P}_{\mathrm{a}}} \cdot \mathrm{e}^{\frac{1.63 \mathrm{i}_{\mathrm{f}} / \mathrm{A}}{\mathrm{T}_{\mathrm{fc}}^{1.334}}}\right)-1\right], \\
& \mathrm{P}_{\mathrm{O}_{2}}=\frac{\mathrm{RH}_{\mathrm{c}} \cdot \mathrm{P}_{\mathrm{H}_{2} \mathrm{O}}}{2}\left[1 /\left(\frac{\mathrm{RH}_{\mathrm{c}} \cdot \mathrm{P}_{\mathrm{H}_{2} \mathrm{O}}}{\mathrm{P}_{\mathrm{C}}} \cdot \mathrm{e}^{\frac{4.1922_{\mathrm{f}} / \mathrm{A}}{\mathrm{T}_{\mathrm{fc}}^{1.334}}}\right)-1\right] \text {, } \\
& \mathrm{P}_{\mathrm{H}_{2} \mathrm{O}}=2.95 \cdot 10^{-2} \mathrm{~T}_{\mathrm{c}}-9.18 \cdot 10^{-5} \mathrm{~T}_{\mathrm{c}}^{2}+1.44 \cdot 10^{-7} \mathrm{~T}_{\mathrm{c}}^{3}-2.18 \text {, } \\
& \mathrm{T}_{\mathrm{c}}=\mathrm{T}_{\mathrm{fc}}-273.15 \text {, } \\
& V_{\mathrm{act}}=-\left[\xi_{1}+\xi_{2} \mathrm{~T}_{\mathrm{fc}}+\xi_{3} \mathrm{~T}_{\mathrm{fc}} \ln \left(\mathrm{C}_{\mathrm{O}_{2}}\right)+\xi_{4} \mathrm{~T}_{\mathrm{fc}} \ln \left(\mathrm{I}_{\mathrm{fc}}\right)\right] \text {, } \\
& \mathrm{C}_{\mathrm{O}_{2}}=\frac{\mathrm{P}_{\mathrm{O}_{2}}}{5.08 \cdot 10^{6}} \cdot \mathrm{e}^{-\frac{498}{\mathrm{Ifc}_{\mathrm{fc}}}} \text {, } \\
& \mathrm{V}_{\Omega}=\mathrm{I}_{\mathrm{fc}}\left(\mathrm{R}_{\mathrm{m}}+\mathrm{R}_{\mathrm{C}}\right) ; \mathrm{R}_{\mathrm{m}}=\frac{\rho_{\mathrm{m}} \mathrm{l}}{\mathrm{A}}, \\
& \rho_{\mathrm{m}}=\frac{181.6\left[1+0.03\left(\frac{\mathrm{I}_{\mathrm{fc}}}{\mathrm{A}}\right)+0.062\left(\frac{\mathrm{T}_{\mathrm{fc}}}{303}\right)^{2}\left(\frac{\mathrm{I}_{\mathrm{fc}}}{\mathrm{A}}\right)^{2.5}\right]}{\left[\Psi-0.634-3\left(\frac{\mathrm{I}_{\mathrm{fc}}}{\mathrm{A}}\right)\right] \mathrm{e}^{4.18 \cdot \frac{\mathrm{f}_{\mathrm{fc}}-303}{\mathrm{~T}_{\mathrm{fc}}}},} \\
& \mathrm{V}_{\text {con }}=-\mathrm{b} \cdot \ln \left(\frac{\mathrm{J}_{\max }-\mathrm{J}}{\mathrm{J}_{\max }}\right) \text {. }
\end{aligned}
$$

The power of the PEM fuel cell stack $\left(\mathrm{P}_{\text {stack }}\right)$ is stated as defined in (10):

$$
\mathrm{P}_{\text {stack }}=\mathrm{V}_{\text {stack }} \cdot \mathrm{I}_{\mathrm{fc}} \text {. }
$$

According to Equations (1) to (9), it is obvious that seven coefficients $\left(\xi_{1}, \xi_{2}, \xi_{3}, \xi_{4}, \Psi, R_{C}\right.$, and b) need to be identified. These parameters are not predetermined in the manufacturer's datasheet. ASO is utilized in optimizing the seven coefficients to own finest values inside their higher and lower limits. Optimization is performed to ensure a precise modeling of PEM fuel cell under study and simulation.

\section{Formulating the Objective Function and Constraints}

Minimizing the sum of the squared error (SSE) between the computed voltage $\left(\mathrm{V}_{\text {com }}\right)$ and measured voltage $\left(\mathrm{V}_{\text {meas }}\right)$ is the objective function $(\mathrm{OF})$ for the modeling of PEM fuel cell, as revealed in (11).

$$
\mathrm{OF}=\min (\mathrm{SSE})=\min \left(\sum_{\mathrm{k}=1}^{\mathrm{M}}\left[\mathrm{V}_{\text {com }}(\mathrm{k})-\mathrm{V}_{\text {meas }}(\mathrm{k})\right]^{2}\right)
$$

The $\mathrm{OF}$ is subjected to constraints that are determined by the lower and upper limits of $\left(\xi_{1}, \xi_{2}, \xi_{3}, \xi_{4}, \Psi, R_{C}\right.$, and $\left.b\right)$.

Minimizing the mean squared error (MSE) represents the OF in some previous studies. To compare the obtained numerical results by ASO with other challenging optimization methods-based results, MSE can be computed as depicted in (12):

$$
\mathrm{MSE}=\frac{\mathrm{SSE}}{\mathrm{M}}
$$

\section{Atom Search Optimizer (ASO)}

Atoms, basic building blocks of all materials, are moving continuously, and their motions are governed by the classical mechanics [30]. Assume that force of interaction is $\mathrm{F}_{\mathrm{i}}$ and force of constraint is $G_{i}$, and they are applied together on the atom i inside an atom arrangement. Subsequently, the 
relationship between acceleration $\mathrm{a}_{\mathrm{i}}$ and mass $\mathrm{m}_{\mathrm{i}}$ of atom is derived by the second law of Newton's laws as shown in (13) $[29,30]$ :

$$
\mathrm{a}_{\mathrm{i}}=\frac{\mathrm{F}_{\mathrm{i}}+\mathrm{G}_{\mathrm{i}}}{\mathrm{m}_{\mathrm{i}}} .
$$

At iteration $t$, the atom $i$ is exposed to interaction force by the atom $j$ in the dimension $d$ and is written using the Lennard-Jones (L-J) potential as [29,30]:

$$
\mathrm{F}_{\mathrm{ij}}^{\mathrm{d}}(\mathrm{t})=\frac{24 \varepsilon(\mathrm{t})}{\sigma(\mathrm{t})}\left[\left(\frac{\sigma(\mathrm{t})}{\mathrm{r}_{\mathrm{ij}}(\mathrm{t})}\right)^{13}-\left(\frac{\sigma(\mathrm{t})}{\mathrm{r}_{\mathrm{ij}}(\mathrm{t})}\right)^{7}\right] \frac{\mathrm{r}_{\mathrm{ij}}(\mathrm{t})}{\mathrm{r}_{\mathrm{ij}}^{\mathrm{d}}(\mathrm{t})},
$$

and:

$$
\mathrm{F}_{\mathrm{ij}}^{\prime}(\mathrm{t})=\frac{24 \varepsilon(\mathrm{t})}{\sigma(\mathrm{t})}\left[\left(\frac{\sigma(\mathrm{t})}{\mathrm{r}_{\mathrm{ij}}(\mathrm{t})}\right)^{13}-\left(\frac{\sigma(\mathrm{t})}{\mathrm{r}_{\mathrm{ij}}(\mathrm{t})}\right)^{7}\right] .
$$

Figure 1 shows the interaction force of atoms against the spacing between atoms. The repulsion is positive, and the attraction is negative; therefore, atoms would not be converging to a certain location. Equation (15) cannot be utilized straightway in optimization, so it can be adapted as:

$$
\begin{gathered}
\mathrm{F}_{\mathrm{ij}}^{\prime}(\mathrm{t})=-\eta(\mathrm{t})\left[2\left(\mathrm{~h}_{\mathrm{ij}}(\mathrm{t})\right)^{13}-\left(\mathrm{h}_{\mathrm{ij}}(\mathrm{t})\right)^{7}\right], \\
\mathrm{h}_{\mathrm{ij}}(\mathrm{t})=\frac{\sigma(\mathrm{t})}{\mathrm{r}_{\mathrm{ij}}(\mathrm{t})} .
\end{gathered}
$$

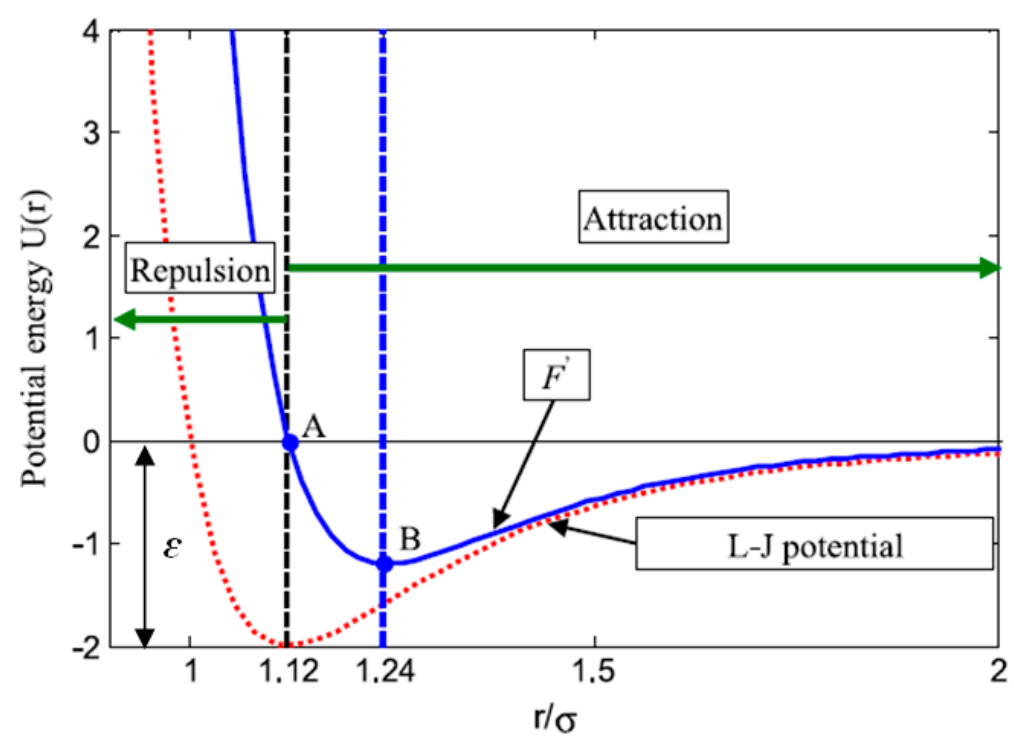

Figure 1. Atoms force against spacing between them [29].

The deepness function is used to set the attraction zone or the repulsion zone that is stated as [28]:

$$
\eta(t)=\alpha\left(1-\frac{t-1}{T}\right)^{3} e^{-\frac{20 t}{T}}
$$

Figure 2 demonstrates $\mathrm{F}^{\prime}$ against $\eta$ when $\mathrm{h}$ varies between 0.9 and 2 . The attraction happens while $h$ is varying from 1.12 to 2 , the repulsion happens while $h$ is varying between 0.9 and 1.12 , and the equilibrium happens while h equals 1.12. Consequently, in ASO, to ameliorate the reconnaissance, repulsion has a lower limit while $\mathrm{F}^{\prime}$ has a lesser value at which $\mathrm{h}=1.1$, and attraction has an upper limit while $\mathrm{F}^{\prime}$ has a bigger value at which $\mathrm{h}=1.24$; thus, $\mathrm{h}$ is stated as: 


$$
h_{i j}(t)=\left\{\begin{array}{cc}
h_{\min } & \frac{r_{i j}(t)}{\sigma(t)}<h_{\min } \\
\frac{r_{i j}(t)}{\sigma(t)} & h_{\min } \leq \frac{r_{i j}(t)}{\sigma(t)} \leq h_{\max } \\
h_{\max } & \frac{r_{i j}(t)}{\sigma(t)}>h_{\max }
\end{array}\right.
$$

$\sigma(\mathrm{t})$ is stated as:

$$
\sigma(t)=\left\|x_{i j}(t), \frac{\sum_{j \in K b e s t} x_{i j}(t)}{K(t)}\right\|_{2},
$$

and:

$$
\left\{\begin{array}{c}
\mathrm{h}_{\min }=\mathrm{g}_{0}+\mathrm{g}(\mathrm{t}) \\
\mathrm{h}_{\max }=\mathrm{u}
\end{array} .\right.
$$

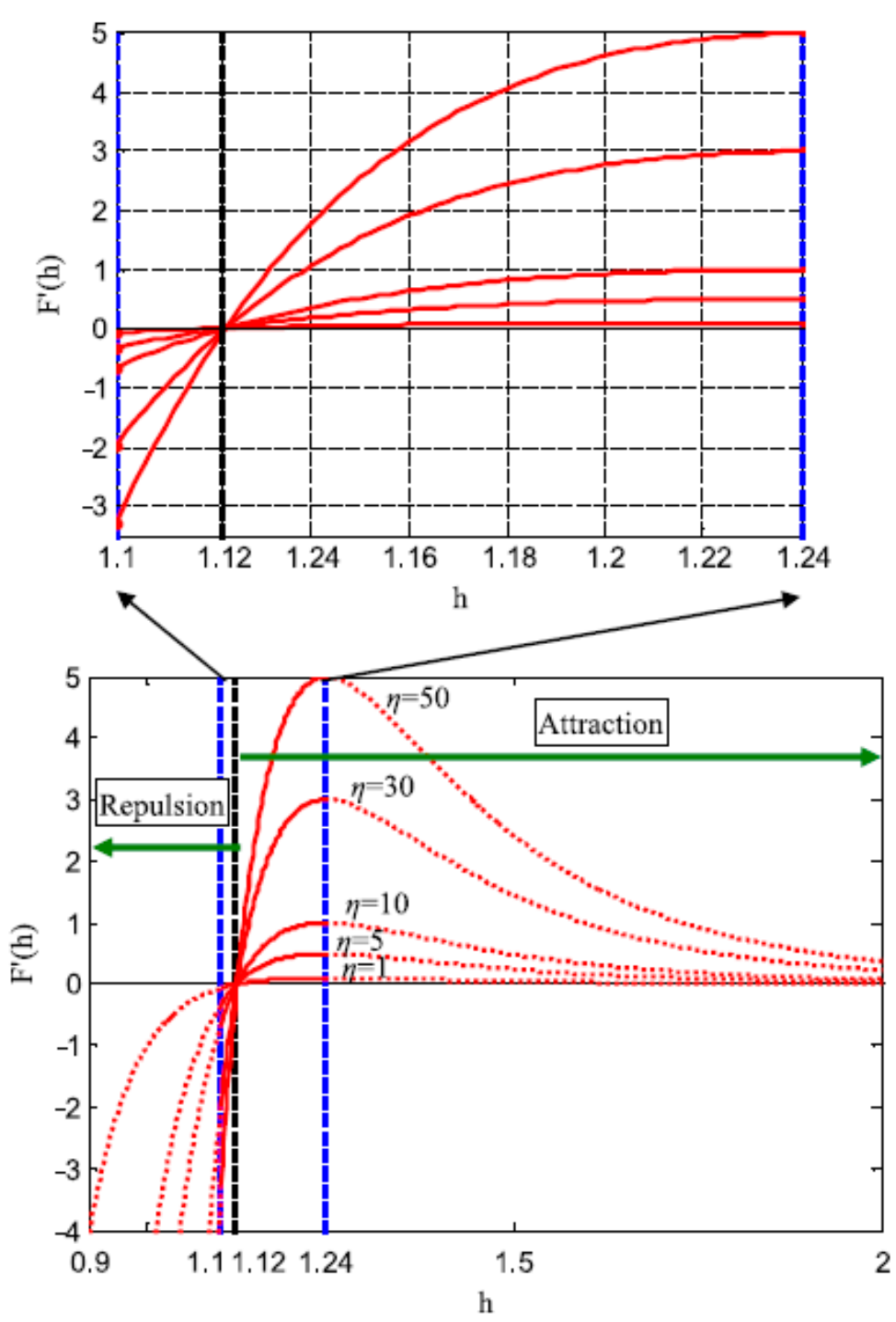

Figure 2. Function $F^{\prime}$ against $\eta$ [28].

Consequently, $\mathrm{u}$ and $\mathrm{g}_{0}$ are equal to 1.24 and 1.1, consecutively. $\mathrm{g}$ symbolizes the drift factor that may transport the procedure from the reconnaissance to the profiteering, which is stated as:

$$
g(t)=0.1 \times \sin \left(\frac{\pi}{2} \times \frac{t}{T}\right) .
$$


Afterwards, total force applied on the atom $\mathrm{i}$ by other atoms is the summation of weighted components in the d-th dimension that is depicted in (23):

$$
F_{i}^{d}(t)=\sum_{j \in K_{\text {best }}} \operatorname{rand}_{j} \cdot F_{i j}^{d}(t) .
$$

From the third law of Newton's laws:

$$
\mathrm{F}_{\mathrm{ij}}=-\mathrm{F}_{\mathrm{ji}}
$$

Molecular dynamics put a geometric constraint that acts a serious task in the atom movement. In ASO, assume that the best atom owns a covalence bond with each atom; therefore, a constraint force is exerted on each atom by the best atom. Hence, the atom i constraint is modified as:

$$
\theta_{i}(t)=\left[\left|\mathbf{x}_{\mathbf{i}}(\mathrm{t})-\mathbf{x}_{\text {best }}(\mathrm{t})\right|^{2}-\mathrm{b}_{\mathrm{i}, \text { best }}^{2}\right]
$$

Therefore, the force of constraint is stated as $[29,30]$ :

$$
G_{i}^{d}(t)=-\lambda(t) \nabla \theta_{i}^{d}(t)=-2 \lambda(t)\left(x_{i}^{d}(t)-x_{\text {best }}^{d}(t)\right) .
$$

By replacement of $2 \lambda$ with $\lambda$ :

$$
G_{i}^{d}(t)=\lambda(t)\left(x_{\text {best }}^{d}(t)-x_{i}^{d}(t)\right) .
$$

The Lagrange multiplier is stated as:

$$
\lambda(\mathrm{t})=\beta \cdot \exp \left(-\frac{20 \mathrm{t}}{\mathrm{T}}\right) .
$$

Consequently, the atom $i$ acceleration at iteration $t\left(a_{i}^{d}(t)\right)$ is stated as:

$$
\begin{gathered}
a_{i}^{d}(t)=\frac{F_{i}^{d}(t)}{m_{i}^{d}(t)}+\frac{G_{i}^{d}(t)}{m_{i}^{d}(t)}=-\alpha\left(1-\frac{t-1}{T}\right)^{3} e^{-\frac{20 t}{T}}, \\
\sum_{j \in K_{b e s t}} \frac{\operatorname{rand}_{j}\left[2 \times\left(h_{i j}(t)\right)^{13}-\left(h_{i j}(t)\right)^{7}\right]}{m_{i}(t)}, \\
\\
\frac{\left(x_{i}^{d}(t)-x_{j}^{d}(t)\right)}{\left\|x_{i}(t)-x_{j}(t)\right\|_{2}}+\beta e^{-\frac{20 t}{T}} \frac{x_{\text {best }}^{d}(t)-x_{i}^{d}(t)}{m_{i}(t)} .
\end{gathered}
$$

If the population of atoms is $N_{P}$, the mass of atom $i\left(m_{i}(t)\right)$ is computed using (30)-(31):

$$
\begin{gathered}
\mathrm{M}_{\mathrm{i}}(\mathrm{t})=\exp \left(-\frac{\text { Fit }_{\mathrm{i}}(\mathrm{t})-\mathrm{Fit}_{\text {best }}(\mathrm{t})}{\text { Fit } \left._{\text {worst }(\mathrm{t})-\text { Fit }_{\text {best }}(\mathrm{t})}\right),}\right. \\
\mathrm{m}_{\mathrm{i}}(\mathrm{t})=\frac{\mathrm{M}_{\mathrm{i}}(\mathrm{t})}{\sum_{\mathrm{j}=1}^{\mathrm{N}_{\mathrm{P}}} \mathrm{M}_{\mathrm{j}}(\mathrm{t})} .
\end{gathered}
$$

In case of minimization, Fit ${ }_{\text {worst }}(t)$ and Fit $t_{\text {best }}(t)$ are the maximum and the minimum fitness values of atoms at the iteration $t$, consecutively. $\mathrm{Fit}_{\mathrm{i}}(\mathrm{t})$ is the function fitness value of the atom $i$ at the iteration t. Fit worst $_{(t)}(t)$ and Fit $_{\text {best }}(t)$ are expressed in (32) and (33), respectively:

$$
\begin{aligned}
\operatorname{Fit}_{\text {worst }}(t) & =\max _{\mathrm{i} \in\left\{1,2, \ldots, \mathrm{N}_{\mathrm{P}}\right\}} \operatorname{Fit}_{\mathrm{i}}(\mathrm{t}), \\
\operatorname{Fit}_{\text {best }}(t) & =\min _{\mathrm{i} \in\left\{1,2, \ldots, \mathrm{N}_{\mathrm{P}}\right\}} \operatorname{Fit}_{\mathrm{i}}(\mathrm{t}) .
\end{aligned}
$$


For simplification, the velocity and the position of the atom $i$ in the iteration $t+1$ is signified as:

$$
\begin{aligned}
& v_{i}^{d}(t+1)=\operatorname{rand}_{i}^{d} v_{i}^{d}(t)+a_{i}^{d}(t), \\
& x_{i}^{d}(t+1)=x_{i}^{d}(t)+v_{i}^{d}(t+1) .
\end{aligned}
$$

In the ASO algorithm, to ameliorate the reconnaissance in earlier iterations, every atom reacts with atoms owning as many better values of fitness as possible. To ameliorate the profiteering in later iterations, every atom reacts with atoms owning as few better values of fitness as possible. K piecemeal decreases as the iterations elapse, and it is computed using the formula stated in (36):

$$
K(t)=N_{P}-\left(N_{P}-2\right) \times \sqrt{t / T} \text {. }
$$

Figure 3 displays the forces in an atom arrangement. The atoms $A_{1}, A_{2}, A_{3}$, and $A_{4}$ have the best values of fitness, so they are considered as the $\mathrm{K}_{\text {best }}$. Each atom in the arrangement repels or attracts each other. Each atom in the arrangement, excluding $A_{1}\left(X_{\text {best }}\right)$, owns a force of constraint via the best atom $\mathrm{A}_{1}$.

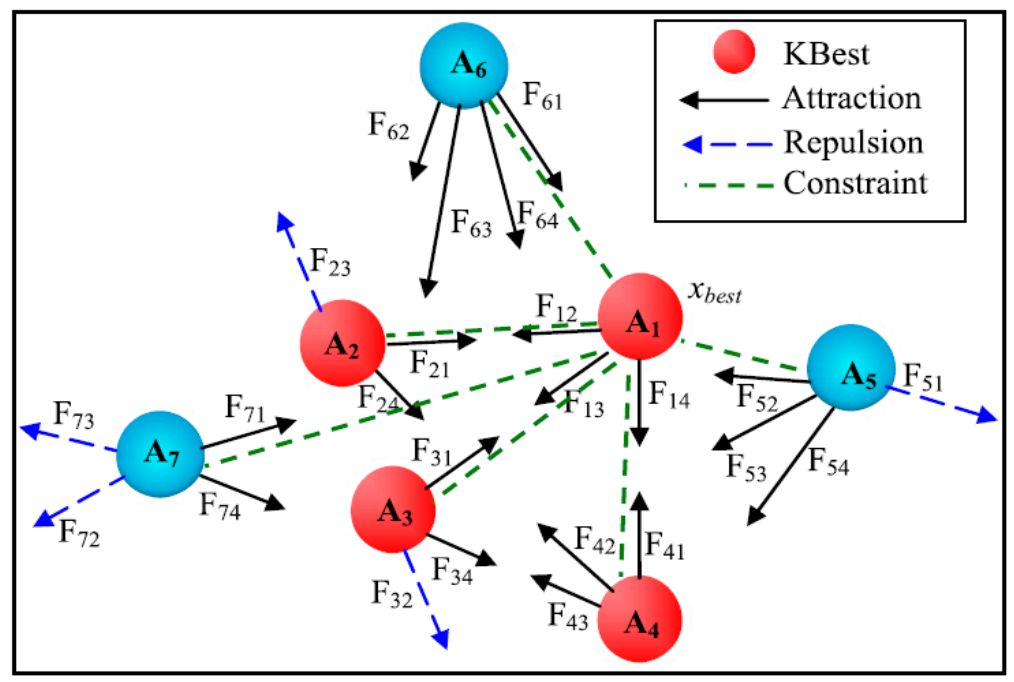

Figure 3. Forces in an atom arrangement through $K_{\text {best }}$ when $K=4$ [29].

The computational procedure of the ASO algorithm is as follows:

Step 1: Randomly initialize a set of atoms $X$ (solutions) and their velocity $v$, and set Fit best $=\infty, t=1, i=1$.

Step 2: Increment $t=t+1$.

Step 3: Increment $\mathrm{i}=\mathrm{i}+1$.

Step 4: Calculate the fitness value Fit $_{i}$.

Step 5: If Fit $_{i}>$ Fit $_{\text {best }}$, set Fit best $_{\text {bit }}=$ Fit $_{i}$ and $X_{\text {best }}=X_{i}$.

Step 6: Calculate the mass $\mathrm{m}_{\mathrm{i}}(\mathrm{t})$ using Equations (30) and (31).

Step 7: Determine its K neighbors using Equation (36).

Step 8: Calculate the force of interaction $F_{i}$ and the force of constraint is $G_{i}$ using Equations (23) and (27), respectively.

Step 9: Update the velocity and the position using Equations (34) and (35), respectively.

Step 10: If $\mathrm{i} \leq \mathrm{N}_{\mathrm{p}}$ go to Step 3 .

Step 11: If $\mathrm{t} \leq \mathrm{T}$, go to Step 2 .

Step 12: Find the best solution so far, $X_{\text {best }}$.

Step 13: Stop. 


\section{Demonstrated Results, Discussions and Validations}

In this section, ASO is utilized to estimate the PEM fuel cell model parameters $\left(\xi_{1}, \xi_{2}, \xi_{3}, \xi_{4}, \Psi, R_{C}, b\right)$. In this study, two models of marketable PEM fuel cells are tested to legalize the proposed ASO-based methodology in a steady-state condition. The lower and upper limits of $\left(\xi_{1}, \xi_{2}, \xi_{3}, \xi_{4}, \Psi, R_{C}, b\right)$ exist in literature as follows [20,25,26]:

$$
\begin{aligned}
& -1.1997 \leq \xi_{1} \leq-0.8532 \\
& 0.001 \leq \xi_{2} \leq 0.005 \\
& 3.6 \cdot 10^{-5} \leq \xi_{3} \leq 9.8 \cdot 10^{-5} \\
& -2.6 \cdot 10^{-4} \leq \xi_{4} \leq-9.54 \cdot 10^{-5} \\
& 13 \leq \Psi \leq 23 \\
& 10^{-4} \leq \mathrm{R}_{\mathrm{C}} \leq 8 \cdot 10^{-4} \\
& 0.0136 \leq \mathrm{b} \leq 0.5
\end{aligned}
$$

The parameters' bounds are the same in all test cases to ensure fair comparisons with other challenging optimization methods.

Both $\mathrm{RH}_{\mathrm{c}}$ and $\mathrm{RH}_{\mathrm{a}}$ are 1. Both $\mathrm{P}_{\mathrm{c}}$ and $\mathrm{P}_{\mathrm{a}}$ are $1 \mathrm{~atm}$. The maximum iterations are 3000. ASO parameters $\left(N_{P}, \alpha, \beta\right)$ are determined by means of trial and error as other challenging heuristic-based optimization methods as shown in Table 1. The finest values of obscure parameters are yielded after executing ASO for some independent runs because of the high haphazardness of such algorithms.

Table 1. Atom search optimization (ASO) adapted controlling parameters.

\begin{tabular}{ccc}
\hline ASO Parameters & SR-12 Modular & 250 W Stack \\
\hline $\mathbf{N}_{\mathbf{P}}$ & 25 & 10 \\
$\boldsymbol{\alpha}$ & 40 & 50 \\
$\boldsymbol{\beta}$ & 0.2 & 0.2 \\
\hline
\end{tabular}

\subsection{Test Case 1}

In this case, a model of SR-12 $500 \mathrm{~W}$ modular PEM fuel cell was tested to regularize the performance of ASO. The datasheet was taken from $[17,18,21,25,26]$ as follows: $n_{\text {cells }}=48, A=62.5 \mathrm{~cm}^{2}$, $1=0.025 \mathrm{~mm}, \mathrm{~J}_{\max }=0.672 \mathrm{~A} / \mathrm{cm}^{2}, \mathrm{~T}_{\mathrm{fc}}=323 \mathrm{~K}, \mathrm{P}_{\mathrm{H}_{2}}=1.47628 \mathrm{~atm}, \mathrm{P}_{\mathrm{O}_{2}}=0.2095 \mathrm{~atm}$. Twenty measurements in $\mathrm{I}-\mathrm{V}$ characteristics of the fuel cell $(\mathrm{M}=20)$ were utilized in optimization using ASO.

The finest estimated parameters of the PEM fuel cell model by ASO are displayed in Table 2. The convergence tendency of the SSE diagram is illustrated in Figure 4, which indicates that SSE obtained by ASO is 0.00203 . MSE can be computed by (12) to result in (MSE $=0.0001015$ ). These SSE and MSE are the smallest values compared to other challenging optimization methods, as shown in Table 3.

Table 2. Estimated parameters by ASO for SR-12 modular.

\begin{tabular}{cccccccc}
\hline Parameter & $\xi_{1}$ & $\xi_{2}$ & $\xi_{3}$ & $\xi_{4}$ & $\Psi$ & $\mathbf{R}_{\mathbf{C}}$ & $\mathbf{b}$ \\
\hline Optimized Value & -0.9217 & 0.0033 & 0.0001 & -0.0001 & 13.7608 & 0.0001 & 0.1497 \\
\hline
\end{tabular}

Table 3. SR-12 modular.

\begin{tabular}{ccccc}
\hline Algorithm & ADE [17] & IGHS [18] & TRADE [21] & ASO \\
\hline MSE & 0.11885 & 0.1039 & 0.247013 & 0.0001015 \\
Algorithm & GOA [25] & GWO [26] & ASO & \\
SSE & 0.0478 & 1.517 & 0.00203 & \\
\hline
\end{tabular}




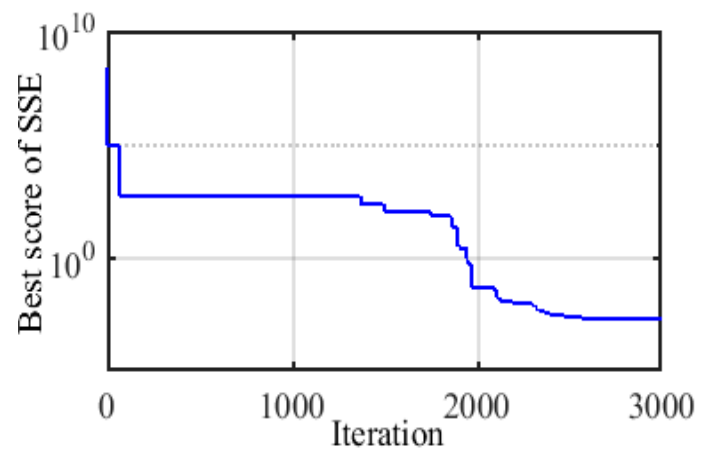

Figure 4. Sum of the squared error (SSE) convergence for SR-12 modular.

The yielded finest results for I-V characteristics of SR-12 modular PEM fuel cell that were estimated by ASO accompanying the experimentation data are displayed in Figure 5a. Closeness between the experimental voltages and computed voltages by ASO-based methodology ensures precision of the yielded optimized values of the obscure seven parameters.

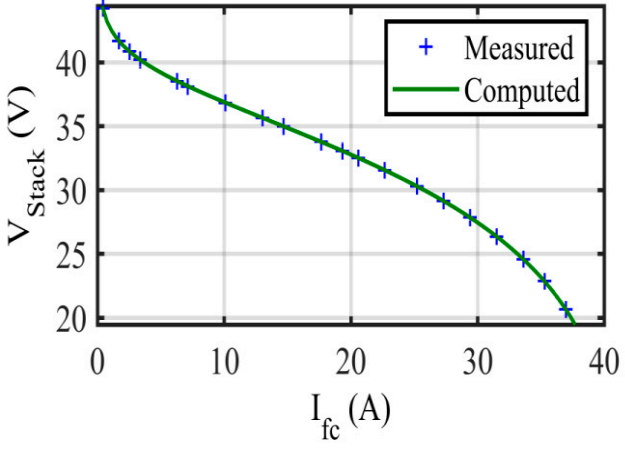

(a) I-V characteristics

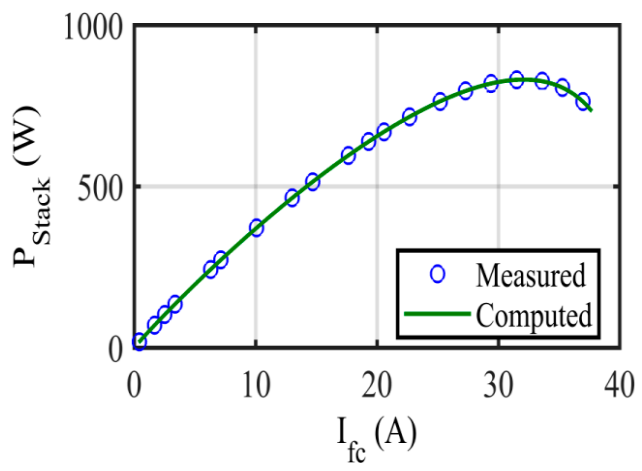

(b) I-P characteristics

Figure 5. Characteristics of SR-12.

The power of the SR-12 modular PEM fuel cell stack was computed using (10) and utilized to characterize the I-P relationship in Figure $5 b$ accompanying the experimentation data. Closeness between the experimental powers and computed powers resulted due to closeness between corresponding voltages.

The I-V and I-P relationships of the SR-12 fuel cell stack needed to be characterized at different operating pressures and temperatures to illustrate ASO functioning at different conditions. In Figure 6, $\mathrm{P}_{\mathrm{H}_{2}} / \mathrm{P}_{\mathrm{O}_{2}}$ are $1.5 / 1 \mathrm{~atm}$ and 3.5/1.5 atm, consecutively, at a fixed temperature of $323 \mathrm{~K}$. It can be noticed that increasing $\mathrm{P}_{\mathrm{H}_{2}} / \mathrm{P}_{\mathrm{O}_{2}}$ results in increasing the output voltage and power of the fuel cell stack.

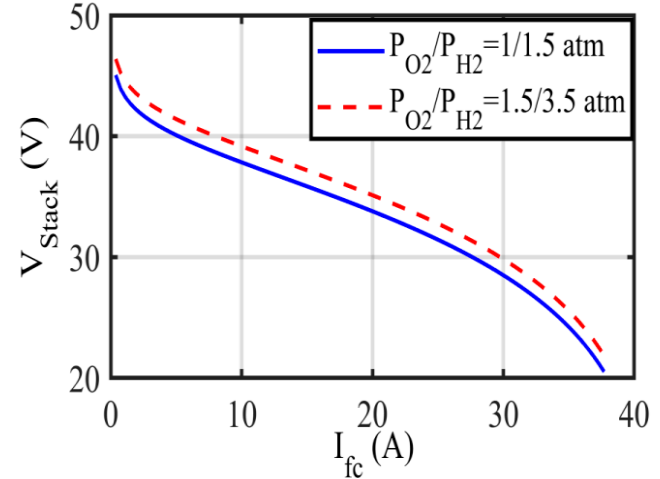

(a) $\mathrm{I}-\mathrm{V}$ characteristics at different pressures

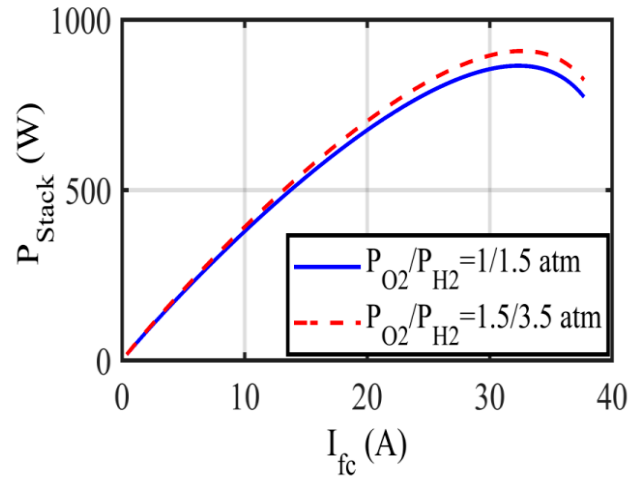

(b) I-P characteristics at different pressures

Figure 6. Characteristics of SR-12 at different pressures. 
Subsequently, the influence of temperature alterations is depicted in Figure 7, where $\mathrm{T}_{\mathrm{fc}}$ is $313 \mathrm{~K}$ and $353 \mathrm{~K}$, consecutively (under a fixed $\mathrm{P}_{\mathrm{H}_{2}} / \mathrm{P}_{\mathrm{O}_{2}}$ of $1 / 1 \mathrm{~atm}$ ). It is clear that increasing temperature causes augmentation of the output voltage and power of the fuel cell stack.

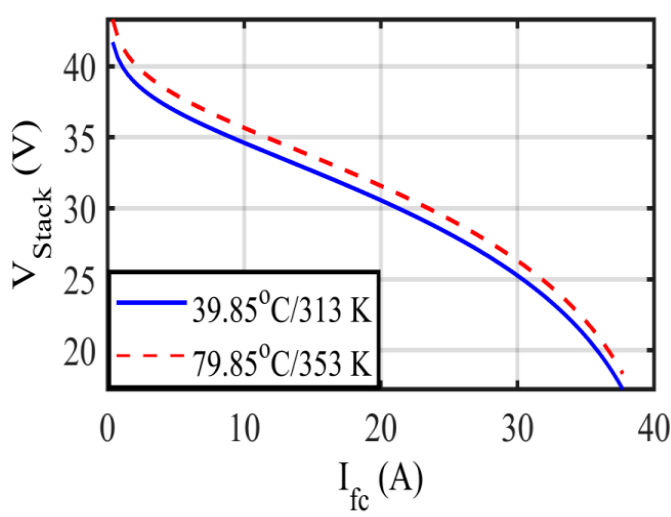

(a) I-V characteristics at different temperatures

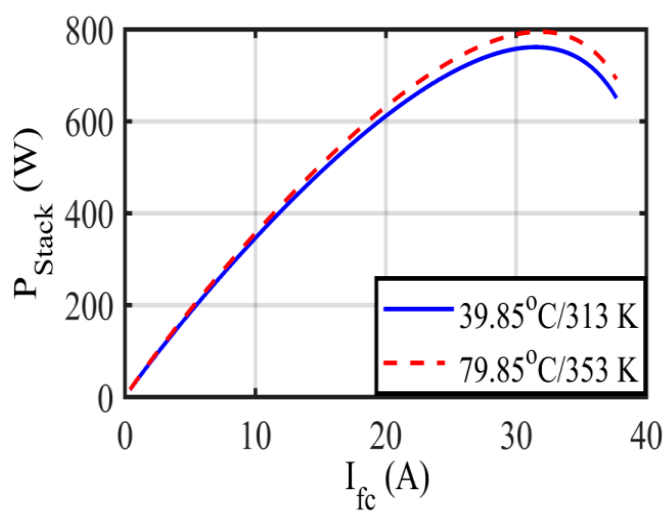

(b) I-P characteristics at different temperatures

Figure 7. Characteristics of SR-12 at different temperatures.

\subsection{Test Case 2}

In this case, the model of the $250 \mathrm{~W}$ PEM fuel cell stack was tested to assure regularity of the performance of ASO. The datasheet was taken from $[8,19,20,22,24,27]$ as follows: $n_{\text {cells }}=24$, $\mathrm{A}=27 \mathrm{~cm}^{2}, 1=0.178 \mathrm{~mm}, \mathrm{~J}_{\max }=0.86 \mathrm{~A} / \mathrm{cm}^{2}, \mathrm{~T}_{\mathrm{fc}}=338.15 \mathrm{~K}, \mathrm{P}_{\mathrm{H}_{2}}=1 \mathrm{~atm}$, and $\mathrm{P}_{\mathrm{O}_{2}}=1 \mathrm{~atm}$. Fifteen measurements in $\mathrm{I}-\mathrm{V}$ characteristics of the fuel cell $(\mathrm{M}=15)$ were utilized in optimization using the ASO-based proposed method.

The finest estimated parameters of the PEM fuel cell model by ASO are presented in Table 4 . The convergence leaning of SSE diagram is displayed in Figure 8, which illustrates that the SSE received from ASO is 0.7346 . This SSE is the lowest value compared to those of other challenging optimization methods, as shown in Table 5. MSE can be computed by (12), resulting in MSE $=0.04897$.

Table 4. Estimated parameters by the ASO for the $250 \mathrm{~W}$ stack.

\begin{tabular}{cccccccc}
\hline Parameter & $\xi_{1}$ & $\xi_{2}$ & $\xi_{3}$ & $\xi_{4}$ & $\Psi$ & $\mathbf{R}_{\mathbf{C}}$ & $\mathbf{b}$ \\
\hline Optimized Value & -1.1132 & 0.0036 & 0.0001 & -0.0002 & 22.1763 & 0.0001 & 0.0248 \\
\hline
\end{tabular}

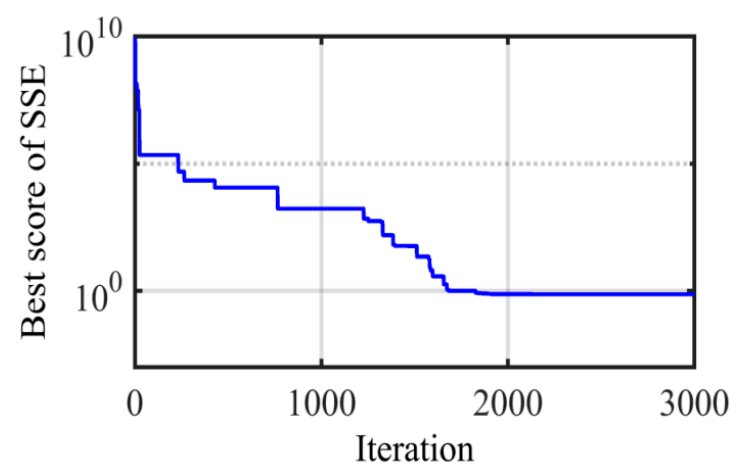

Figure 8. SSE convergence for the $250 \mathrm{~W}$ stack.

Table 5. $250 \mathrm{~W}$ PEM fuel cell stack.

\begin{tabular}{cccccccc}
\hline Algorithm & ARNA-GA [8] & BBO-M [19] & STLBO [20] & HADE [22] & MVO [24] & BIPOA [27] & ASO \\
\hline SSE & 8.1039 & 7.6165 & 7.6266 & 7.9908 & 3.5846 & 7.9416 & 0.7346 \\
\hline
\end{tabular}


The obtained finest results for the I-V characteristics of the $250 \mathrm{~W}$ PEM fuel cell stack that were estimated by ASO accompanying the experimentation data are displayed in Figure 9a. Closeness between the experimental voltages and computed voltages by ASO-based methodology ensures precision of the got optimized values of the obscure seven parameters.

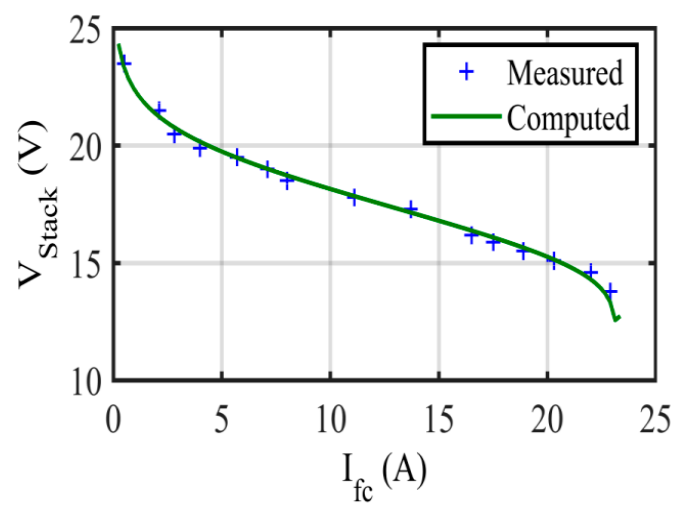

(a) I-V characteristics

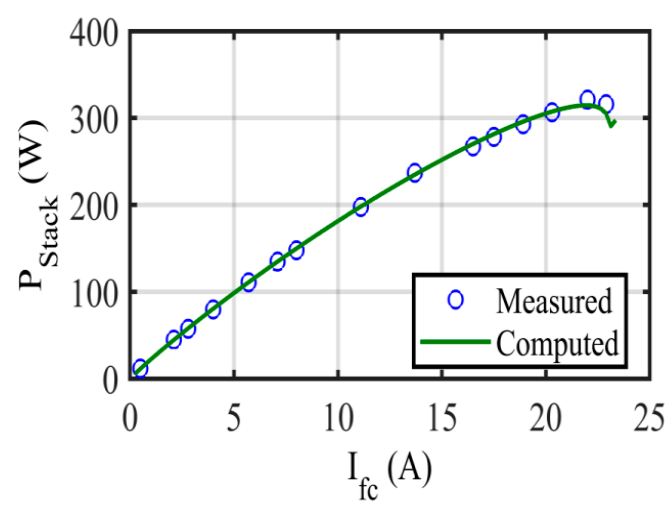

(b) I-P characteristics

Figure 9. Characteristics of the $250 \mathrm{~W}$ stack.

The power of the $250 \mathrm{~W}$ PEM fuel cell stack is computed using (10) and utilized to characterize the I-P relationship in Figure $9 \mathrm{~b}$ accompanying the experimentation data. Nearness between the experimental voltages and computed voltages causes nearness between corresponding powers.

To verify ASO functioning at different conditions, the I-V and I-P relationships of the $250 \mathrm{~W}$ fuel cell stack needed to be characterized at different operating pressures and temperatures. In Figure 10, $\mathrm{P}_{\mathrm{H}_{2}} / \mathrm{P}_{\mathrm{O}_{2}}$ are 1.5/1.5 atm and 3/2.5 atm, consecutively, at a fixed temperature of $338 \mathrm{~K}$. It can be observed that increasing $\mathrm{P}_{\mathrm{H}_{2}} / \mathrm{P}_{\mathrm{O}_{2}}$ causes an increase in the output voltage and power of the fuel cell stack.

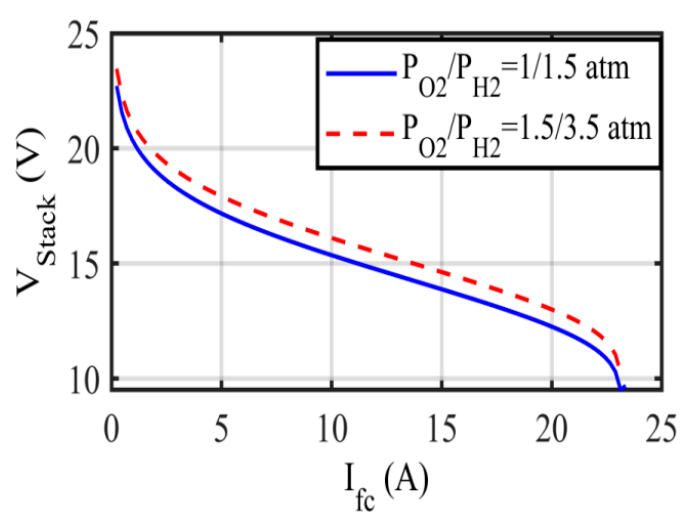

(a) I-V characteristics at different pressures

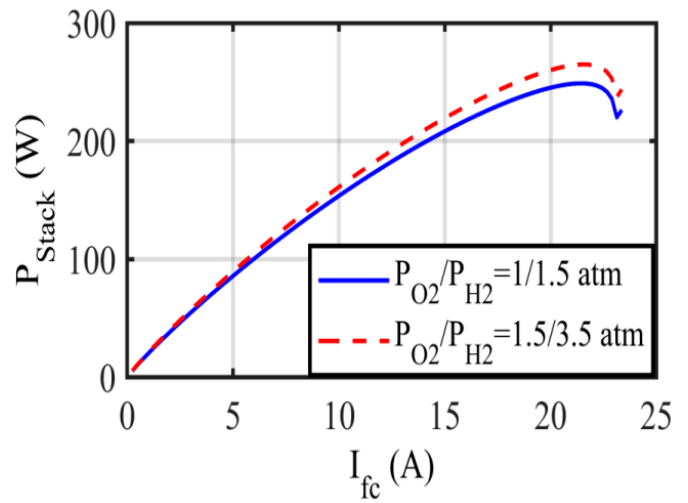

(b) I-P characteristics at different pressures

Figure 10. Characteristics of the $250 \mathrm{~W}$ stack at different pressures.

Afterwards, the influence of the changing temperature is displayed in Figure 11, where $\mathrm{T}_{\mathrm{fc}}$ is $313 \mathrm{~K}$ and $353 \mathrm{~K}$, consecutively (under a fixed $\mathrm{P}_{\mathrm{H}_{2}} / \mathrm{P}_{\mathrm{O}_{2}}$ of $1 / 1 \mathrm{~atm}$ ). It is obvious that augmentation of temperature results in increasing the output voltage and power of the fuel cell stack.

Finally, performance measures using parametric tests to testify the robustness of the ASO results were made. Table 6 summarizes the ASO executions over 100 independent runs and associated indicators in terms of Best, Worst, standard deviation (STD), Mean, and Variance of SSE values to check the robustness and consistency. It can be said here that the smaller values of STD and variance prove the robustness of the obtained results and indicate that the adapted ASO control parameters were carefully selected. 


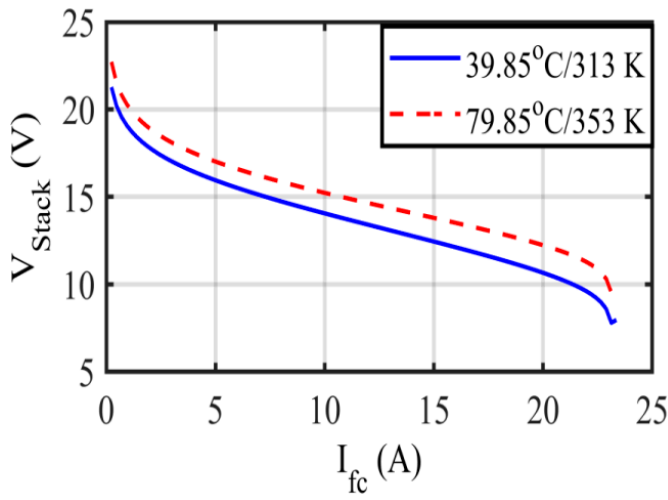

(a) I-V characteristics at different temperatures

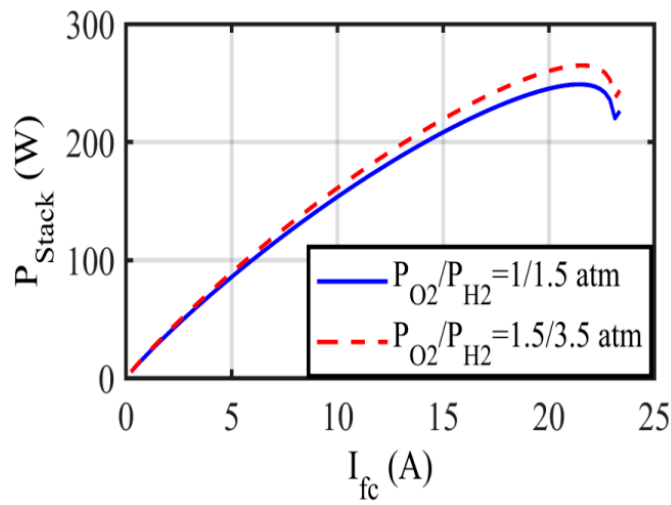

(b) I-P characteristics at different temperatures

Figure 11. Characteristics of the $250 \mathrm{~W}$ stack at different temperatures.

Table 6. ASO-adapted controlling parameters.

\begin{tabular}{lcc}
\hline \multicolumn{1}{c}{ Factor } & SR-12 Modular & 250 W Stack \\
\hline Best value of SSE & 0.00203 & 0.7346 \\
Worst value of SSE & 0.00304 & 1.0903 \\
Mean value of SSE & 0.00251 & 0.9156 \\
STD value of SSE & $2.94 \times 10^{-4}$ & 0.0945 \\
Variance of SSE & $8.71 \times 10^{-8}$ & 0.0089 \\
Average processing time per run (s) & 25.50 & 20.10 \\
\hline
\end{tabular}

\section{Conclusions}

ASO-based methodology has been introduced for estimating the PEM fuel cell model parameters to assure precise modeling and simulation. The finest values of obscure parameters are generated by the ASO, for two real commercial PEM fuel cell models. The computed results of two models are compared with measured results to illustrate ASO proper functioning. Good fittings between the measured and computed voltages were evidenced through various plots and insignificant values of SSE. Comparisons between the obtained results by the ASO and other recent challenging optimization method-based results indicate the viability and qualification of the proposed ASO-based methodology. Finally, performance measures were made which reprove the good performance and robustness of the ASO-realized results. Therefore, the authors can recommend ASO as a new optimization tool for other engineering complicated problems, which really still needs further verifications.

Author Contributions: The present work was developed with following contributions: Conceptualization, methodology, software, validation, formal analysis, investigation, data curation and writing-original draft preparation, A.M.A.; writing—review and editing, A.A.E.; G.M.S. as supervisor.

Funding: This research was funded by deanship of Scientific Research, Northern Border University, grant number ENG-2018-3-9-F-7813. The APC was funded by deanship of Scientific Research, Northern Border University.

Acknowledgments: The authors gratefully acknowledge the approval and the support of this research study by the grant no. ENG-2018-3-9-F-7813 from the Deanship of Scientific Research at Northern Border University, Arar, KSA.

Conflicts of Interest: The funders had no role in the design of the study; in the collection, analyses, or interpretation of data; in the writing of the manuscript, or in the decision to publish the results.

\section{Nomenclature}

\section{E}

$\mathrm{V}_{\text {act }}$

$\mathrm{V}_{\Omega}$

$\mathrm{V}_{\text {con }}$ open circuit potential

activation over-voltage apiece cell

ohmic voltage drop apiece cell

concentration over-voltage apiece cell 


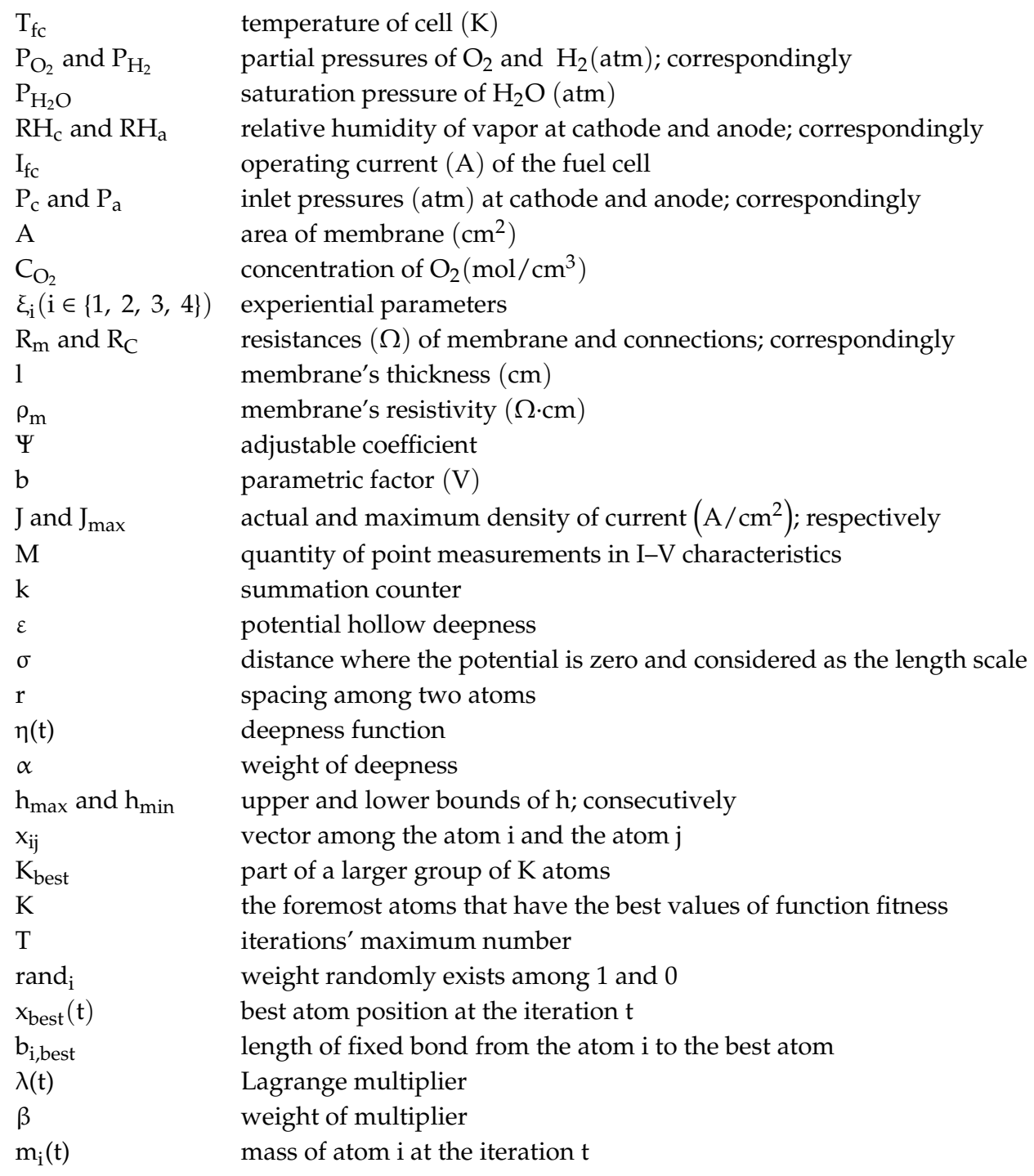

\section{References}

1. Alshehri, F.; Suarez, V.G.; Torres, J.L.R.; Perilla, A.; Van Der Meijdena, M.A.M.M. Modelling and Evaluation of PEM Hydrogen Technologies for Frequency Ancillary Services in Future Multi-Energy Sustainable Power Systems. Heliyon 2019, 5, e01396. [CrossRef]

2. Satpathy, S.; Padhee, S.; Bhuyan, K.C.; Ingale, G.B. Mathematical modelling and voltage control of fuel cell. In Proceedings of the International Conference on Energy Efficient Technologies for Sustainability (ICEETS), Nagercoil, India, 7-8 April 2016. [CrossRef]

3. Priya, K.; Sathishkumar, K.; Rajasekar, N. A comprehensive review on parameter estimation techniques for Proton Exchange Membrane fuel cell modelling. Renew. Sustain. Energy Rev. 2018, 93, 121-144. [CrossRef]

4. Papurello, D.; Silvestri, S.; Tomasi, L.; Belcari, I.; Biasioli, F.; Santarelli, M. Biowaste for SOFCs. Energy Procedia 2016, 101, 424-431. [CrossRef]

5. Santarelli, M. Carbon recovery and re-utilization (CRR) from the exhaust of a solid oxide fuel cell (SOFC): Analysis through a proof-of-concept. J. CO 2 Util. 2017, 18, 206-221. [CrossRef]

6. Martin, I.S.; Ursua, A.; Sanchis, P. Modelling of PEM Fuel Cell Performance: Steady-State and Dynamic Experimental Validation. Energies 2014, 7, 670-700. [CrossRef]

7. El-Fergany, A.A. Extracting optimal parameters of PEM fuel cells using salp swarm optimizer. Renew. Energy 2018, 119, 641-648. [CrossRef]

8. Zhang, L.; Wanga, N. An adaptive RNA genetic algorithm for modeling of proton exchange membrane fuel cells. Int. J. Hydrogen Energy 2013, 38, 219-228. [CrossRef] 
9. Tafaoli-Masoule, M.; Bahrami, A.; Elsayed, E.M. Optimum design parameters and operating condition for maximum power of a direct methanol fuel cell using analytical model and genetic algorithm. Energy 2014, 70, 643-652. [CrossRef]

10. Priya, K.; Babu, T.; Balasubramanian, K.; Kumar, K.; Rajaseka, N. A novel approach for fuel cell parameter estimation using simple Genetic Algorithm. Sustain. Energy Technol. Assess. 2015, 12, 46-52. [CrossRef]

11. Rajaseka, N.; Jacob, B.; Balasubramanian, K.; Priya, K.; Sangeetha, K.; Babu, T.S. Comparative study of PEM fuel cell parameter extraction using Genetic Algorithm. Ain Shams Eng. J. 2015, 6, 1187-1194. [CrossRef]

12. Salim, R.I.; Noura, H.; Fardoun, A. A Parameter identification approach of a PEM fuel cell stack using particle swarm optimization. In Proceedings of the ASME 2013 11th International. Conference on Fuel Cell Science, Engineering and Technolog, Minneapolis, MA, USA, 14-19 July 2013. [CrossRef]

13. Chang, K.Y. The optimal design for PEMFC modeling based on Taguchi method and genetic algorithm neural networks. Int. J. Hydrogen Energy 2011, 36, 13683-13694. [CrossRef]

14. Askarzadeh, A.; Rezazadeh, A. A new heuristic optimization algorithm for modeling of proton exchange membrane fuel cell: Bird mating optimizer. Int. J. Energy Res. 2013, 37, 1196-1204. [CrossRef]

15. Dai, C.; Chen, W.; Cheng, Z.; Li, Q.; Jiang, Z.; Jia, J. Seeker optimization algorithm for global optimization: A case study on optimal modelling of proton exchange membrane fuel cell. Int. J. Electr. Power Energy Syst. 2011, 33, 369-376. [CrossRef]

16. Guarnieri, M.; Negro, E.; Noto, V.; Alotto, P. A selective hybrid stochastic strategy for fuel-cell multi-parameter identification. J. Power Sources 2016, 332, 249-264. [CrossRef]

17. Cheng, J.; Zhang, G. Parameter fitting of PEMFC models based on adaptive differential evolution. Int. J. Electr. Power Energy Syst. 2014, 62, 189-198. [CrossRef]

18. Askarzadeh, A.; Rezazadeh, A. An innovative global harmony search algorithm for parameter identification of a PEM fuel cell model. IEEE Trans. Ind. Electron. 2012, 59, 3473-3480. [CrossRef]

19. Niu, Q.; Zhang, L.; Li, K. A biogeography-based optimization algorithm with mutation strategies for model parameter estimation of solar and fuel cells. Energy Convers. Manag. 2014, 86, 1173-1185. [CrossRef]

20. Niu, Q.; Zhang, H.; Li, K. An improved TLBO with elite strategy for parameters identification of PEM fuel cell and solar cell models. Int. J. Hydrogen Energy 2014, 39, 3837-3854. [CrossRef]

21. Gong, W.; Yan, X.; Xiaobo, L.; Cai, Z. Parameter extraction of different fuel cell models with transferred adaptive differential evolution. Energy 2015, 86, 139-151. [CrossRef]

22. Sun, Z.; Wang, N.; Bi, Y.; Srinivasan, D. Parameter identification of PEMFC model based on hybrid adaptive differential evolution algorithm. Energy 2015, 90, 1334-1341. [CrossRef]

23. Sankar, K.; Jana, A.K. Dynamics and estimator-based nonlinear control of a PEM fuel cell. IEEE Trans. Control Syst. Technol. 2018, 26, 1124-1131. [CrossRef]

24. Fathy, A.; Rezk, H. Multi-verse optimizer for identifying the optimal parameters of PEMFC model. Energy 2018, 143, 634-644. [CrossRef]

25. El-Fergany, A.A. Electrical characterisation of proton exchange membrane fuel cells stack using grasshopper optimiser. IET Renew. Power Gener. 2018, 12, 9-17. [CrossRef]

26. Ali, M.; El-Hameed, M.A.; Farahat, M.A. Effective parameters' identification for polymer electrolyte membrane fuel cell models using grey wolf optimizer. Renew. Energy 2017, 111, 455-462. [CrossRef]

27. Yang, S.; Wang, N. A novel P systems based optimization algorithm for parameter estimation of proton exchange membrane fuel cell model. Int. J. Hydrogen Energy 2012, 37, 8465-8476. [CrossRef]

28. Zhao, W.; Wanga, L.; Zhang, Z. Atom search optimization and its application to solve a hydrogeologic parameter estimation problem. Knowl.-Based Syst. 2019, 163, 283-304. [CrossRef]

29. Zhao, W.; Wanga, L. A novel atom search optimization for dispersion coefficient estimation in groundwater. Future Gener. Comput. Syst. 2019, 91, 601-610. [CrossRef]

30. Goldstein, H.; Poole, C.P.; Safko, J.L. Classical Mechanics, 3rd ed.; Addison Wesley: Boston, MA, USA, 2001.

(C) 2019 by the authors. Licensee MDPI, Basel, Switzerland. This article is an open access article distributed under the terms and conditions of the Creative Commons Attribution (CC BY) license (http://creativecommons.org/licenses/by/4.0/). 